\title{
Quantifying Urban Saw Timber Abundance and Quality in Southeastern Lower Michigan, U.S.
}

\author{
David W. MacFarlane
}

\begin{abstract}
There is a growing need for society to use resources efficiently, including effective use of dead and dying trees in urban areas. Harvesting saw timber from urban trees is a high-end use, but currently, much urban wood ends up in landfills or is used for wood chips or biomass fuel. To assess the general feasibility of harvesting urban wood, a regional estimate of urban saw timber quantity, quality, and availability was developed for a 13-county area in southeastern lower Michigan, U.S. Conservatively, over $16,000 \mathrm{~m}^{3}\left(560,000 \mathrm{ft}^{3}\right)$ of urban saw timber is estimated to become available each year in the study area from dead and dying trees, enough to supply the minimum annual needs of five small sawmills. The quality of wood in urban softwoods was generally low but comprised only a relatively small portion (10\%) of urban wood. Wood quality of urban-grown hardwoods was comparable to that found in forests in the region, although the absolute volume was nine times less. Although there are potential concerns with harvesting urban trees for saw timber such as low availability and poor wood quality, the results of this study suggest that many of them may be unfounded.
\end{abstract}

Key Words. Saw timber; urban forestry; wood products; wood recycling.

The value of trees in urban areas has been given considerable attention, in particular for improving aesthetics, environmental quality (McPherson et al. 1999), and property values (Scott and Betters 2000). For example, recent studies have highlighted the significant contribution of urban trees to carbon sequestration (Johnson and Gerhold 2001; Nowak and Crane 2002). The wood products potential of urban trees is typically not fully realized (Bratkovich 2001; Solid Waste Association of North America 2002; Sherrill 2003), although it is sometimes among the listed values for them (Scott and Betters 2000), often because of a perceived lack of quality wood in urban trees, logistical issues associated with harvesting commercial wood that may make it economically unattractive or infeasible, and an associated lack of social infrastructure geared toward using or recycling urban wood.

The perceived lack of value for urban trees comes from legitimate concerns about foreign objects in urban trees such as nails, stone, or even signage (Sherrill 2003). However, the advent of portable sawmills with inexpensive and easy-tochange blades (e.g., Wood-Mizer ${ }^{\circledR}$, Wood-Mizer Products Inc., Indianapolis, IN; Bratkovich 2001) as well as routine metal detection equipment on sawmill feed lines (Kerry Murphy, Weyerhauser Inc., pers. comm.) greatly reduces the impact of foreign objects in urban tree wood. Wood quality is also an important issue, however. Many urban trees are not growing under optimal conditions for saw timber production attributable to stressful site conditions and exhibit an open growth form that promotes short bole lengths and large branch knots that reduce wood quality (DeBell et al. 1994; Uusitalo and Isotalo 2005).

The main logistical problem for harvesting urban wood is that it primarily becomes available through the random death of trees and is only in abundant supply through catastrophic mortality events, e.g., the recent large-scale mortality of urban trees caused by exotic, invasive tree pests, including emerald ash borer (Agrilus plannipennis) (Poland and McCullough 2006) and Asian longhorned beetle (Anoplophora glabripennis) (Nowak et al. 2001). Other logistical concerns relate to the accessibility of urban trees for commercial harvest, because they may have to be cut into small sections to be removed safely; felling urban trees in log lengths may create excessive liability attributable to nearby hazards (but see Sherrill 2003 for suggestions on efficient and safe removal).

Recent studies by Bratkovich (2001) and Sherrill (2003) have compiled evidence suggesting that harvesting urban saw timber is not only feasible, but may also be profitable. However, no previous study has systematically estimated both the potential availability and quality of urban saw timber over a geographic region. Without specific information regarding wood quality and availability, it is difficult to generalize about the potential for harvesting saw timber from urban trees.

The goal of this study was to quantify the abundance, quality, and accessibility of urban saw timber in southeastern 
lower Michigan, U.S. using systematic inventory procedures across different urban land types and landownerships (both public and private land). Motivation for this research arose from an immediate need to address economic losses associated with an abundance of dead and dying street, park, and backyard trees killed by emerald ash borer in southeastern lower Michigan and a general desire to comprehend the potential for recovering urban saw timber.

\section{METHODS}

\section{Study Area}

The study area was comprised of urban portions of 13 counties in southeastern lower Michigan (Table 1, listed in descending order of urban land cover), which constitute the core 13 counties quarantined by the Michigan Department of Agriculture to control the spread of emerald ash borer (the beetle has since spread beyond this region). A statewide land use/ land cover (LULC) classification system (IFMAP, MDNR 2003) was used to define urban areas in the 13-county region. Four of 37 IFMAP classes were deemed to represent an "urban" condition: (1) low-intensity urban; (2) high-intensity urban; (3) roads/paved (which includes areas appurtenant to roads and large paved areas such as parking lots); and (4) parks and golf courses; the first three explicitly comprise urban types in IFMAP and the last was added to represent developed greenspace appurtenant to urban land use. The remaining IFMAP classes were combined into one "nonurban" stratum that was not considered part of the potential sample space (Table 1). For this study, only roads and paved areas associated with urban areas were of interest; wood from trees associated with other roads and paved areas (e.g., roads traversing farm fields) was not of interest. The fraction of all roads and paved areas that were urban, as opposed to other roads, was approximated as proportional to the total land area that was under high-intensity and low-intensity urban land use (Table 1). Thus, the total urban land area was estimated for each county as the sum of high- and low-intensity urban land use, parks and golf courses, and "urban" roads and paved areas (Table 1).

\section{Inventory Methods}

A stratified, multistage sampling technique (Shiver and Borders 1996) was used to assess the quality and quantity of saw timber over different portions of the urban landscape. An accuracy assessment by NOAA CSCC-CAP (2003) suggested that IFMAP most accurately represented LULC types when classified map pixels $(30 \mathrm{~m} \times 30 \mathrm{~m}[99 \mathrm{ft} \times 99 \mathrm{ft}])$ were aggregated into larger homogeneous blocks (at least $90 \mathrm{~m} \times$ $90 \mathrm{~m}[297 \mathrm{ft} \times 297 \mathrm{ft}])$. Thus, the grid of Michigan public survey quarter-quarter sections (QQSs) were chosen to define

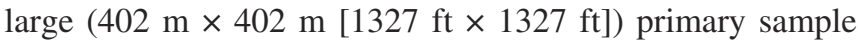
units from which representative urban areas could be selected.

During the first stage of sampling, random QQSs were chosen within the 13-county area. If the randomly selected QQS was composed of a relatively homogeneous block of one of three urban types (high-intensity urban, low-intensity urban, or parks and golf courses), then it was accepted as a sample location; if not, it was rejected. The roads and paved LULC type was excepted because it never formed relatively homogeneous blocks but was a linear network that traversed portions of QQS blocks. Instead, roads and paved areas were sampled within randomly selected blocks dominated by either high-intensity or low-intensity urban areas such that only

Table 1. Urban land use composition in 13 counties in southeastern lower Michigan based on a statewide classified satellite image (IFMAP, MDNR 2003).

\begin{tabular}{|c|c|c|c|c|c|c|c|}
\hline County & Area (ha) & $\begin{array}{l}\text { Parks and } \\
\text { golf }\end{array}$ & $\begin{array}{l}\text { High-intensity } \\
\text { urban }\end{array}$ & $\begin{array}{l}\text { Low-intensity } \\
\text { urban }\end{array}$ & $\begin{array}{l}\text { Roads/paved } \\
\text { (urban + other) }\end{array}$ & $\%$ Urban & $\%$ Nonurban \\
\hline Wayne & 166,482 & $2.24 \%$ & $15.29 \%$ & $13.17 \%$ & $5.72 \%+14.37 \%$ & $36.42 \%$ & $63.58 \%$ \\
\hline Oakland & 234,912 & $1.89 \%$ & $5.93 \%$ & $8.72 \%$ & $1.33 \%+7.72 \%$ & $17.87 \%$ & $82.13 \%$ \\
\hline Genesee & 168,203 & $0.60 \%$ & $4.06 \%$ & $6.69 \%$ & $0.69 \%+5.75 \%$ & $12.04 \%$ & $87.96 \%$ \\
\hline Ingham & 145,169 & $0.54 \%$ & $3.16 \%$ & $3.32 \%$ & $0.33 \%+4.70 \%$ & $7.34 \%$ & $92.66 \%$ \\
\hline Monroe & 144,466 & $0.07 \%$ & $2.12 \%$ & $2.08 \%$ & $0.20 \%+4.60 \%$ & $4.47 \%$ & $95.53 \%$ \\
\hline Jackson & 187,313 & $0.55 \%$ & $1.08 \%$ & $2.31 \%$ & $0.12 \%+3.49 \%$ & $4.05 \%$ & $95.95 \%$ \\
\hline St. Clair & 190,407 & $0.22 \%$ & $1.20 \%$ & $2.02 \%$ & $0.12 \%+3.61 \%$ & $3.56 \%$ & $96.44 \%$ \\
\hline Shiawassee & 140,056 & $0.05 \%$ & $1.18 \%$ & $1.18 \%$ & $0.09 \%+3.90 \%$ & $2.51 \%$ & $97.49 \%$ \\
\hline Lenawee & 197,129 & $0.00 \%$ & $0.71 \%$ & $1.29 \%$ & $0.07 \%+3.66 \%$ & $2.08 \%$ & $97.92 \%$ \\
\hline
\end{tabular}


urban roads and paved areas would be sampled (as described previously).

For the second stage of sampling, field crews visited each selected QQS sample unit and systematically sampled a variable number of variable-area plots that combined to cover urban portions of the total QQS area. The field crew began from an arbitrarily determined point along the edge of a QQS (generally determined by road access) and then moved across the QQS systematically in a serpentine pattern. Permission to sample on private land was obtained in the field, or occasionally in advance; a portion of potential sample space was not sampled as a result of lack of landowner permission. Variable area rectangular plots were systematically established using one of the following three methods applied to the four different IFMAP LULC classes:

1. If the area was either high- or low-intensity urban residential or commercial, each ownership was considered a variable area plot. Lot dimensions (property boundaries within the QQS) were approximated by a rectangle and all trees inside the rectangle were part of the potential sample population (including all buildings, paved and mowed areas within the property boundaries).

2. Roads/paved areas were measured as variable area rectangles bounded by the outer edge of sidewalks, curbs, or pavement; as such, they included pavement sidewalks and mowed areas if they were between the sidewalk and the curb or pavement. Trees that were growing outside of this envelope (most typically trees that were planted between the sidewalk and a lawn or structure) were not considered as road trees/paved area trees (these trees ended up in one of the other urban stratum).

3. If the area was a park or a golf course, then beginning from an arbitrary starting point along the edge of the QQS, the field crew defined a series of plot boundary lines that were approximately equidistant between two areas of treed space (e.g., two rows of planted trees along a fairway) creating variable area rectangular plots, which included intervening areas between groups of trees or isolated trees (e.g., mowed grass).

The third stage of sampling involved selecting sample trees of all species within plots that met the common minimum size standard for saw timber trees in Michigan: $20 \mathrm{~cm}$ (8 in) or greater stem diameter at breast height $(1.37 \mathrm{~m}[4.5 \mathrm{ft}]) \mathrm{dbh}$. Live, dying, standing dead trees were all measured; stumps were measured at stump height (typically $\approx 10$ to $20 \mathrm{~cm}$ [4 to 8 in]) aboveground level. On each tree selected, the following was recorded for estimating saw timber quantity, quality, and accessibility: species (if identifiable, e.g., on stumps and dead trees), stem diameter (at breast or stump height as above), and total tree height and total saw timber log length in the main stem to an approximately $20 \mathrm{~cm}$ (4 in) top diameter outside bark (DOB) (measured with a Wheeler ${ }^{\circledR}$ pentaprism, Forestry Suppliers Inc., Jackson, MS), also known as "merchantable" height (Avery and Burkhart 1994). If the main stem forked, the largest of the forks was followed to assess merchantable height; the other forks were considered part of the crown's branches.

The number of $2.4 \mathrm{~m}(8 \mathrm{ft})$ branch $\operatorname{logs}$ in a tree's crown with a minimum $20 \mathrm{~cm}$ (4 in) small end diameter DOB in the tree's crown $(8 \mathrm{ft}[2.4 \mathrm{~m}]$ is the standard log length on Michigan timberlands) was also tallied on any tree with large enough branches in its crown. In typical forest inventories, tree branches are not tallied and saw timber volume is estimated only for the main stem using information on merchantable height, dbh, and some geometric model of a tree's stem (e.g., a stem taper model; Zakrzewski and MacFarlane 2006). Urban (i.e., open)-grown trees have a much greater proportion of wood and larger branches in their crowns relative to forest-grown grown trees, however, so merchantable (sense Avery and Burkhart 1994) crown wood was tallied to account for this potential source of saw timber.

To assess wood quality, each tree was assigned a saw log grade using six grading classes for hardwoods (Rast et al. 1973): (0) no saw volume, (1) grade 1 saw timber, (2) grade 2 saw timber, (3) grade 3 saw timber, (4) construction grade, and (5) local use class, which aligned with tree grading classes used by the U.S.D.A. Forest Service in the national forest inventory (Miles et al. 2001). Only four grading classes were used for softwoods: (0) no saw volume, (1) grade 1 saw timber, (2) grade 2 saw timber, and (3) grade 3 saw timber, consistent with common softwood grading rules (Avery and Burkhart 1994). Crown logs were not graded as a result of lack of an objective standard for doing so.

To assess the accessibility of merchantable wood in it, each tree was classified into one of three accessibility classes representing the effort that would be involved in extracting the timber from the tree:

1. Easily accessible = tree could be cut into relatively long sections and could be felled with minimal risk of property damage; cut sections could be loaded readily onto a vehicle for transport.

2. Moderately accessible $=$ tree could be cut into merchantable-length sections but would require additional effort to access with enhanced risk of property damage; cut sections would have to be transported a modest distance to be loaded onto a vehicle for transport (a truck could not drive up near the tree).

3. Difficult to access $=$ much of the tree would have to be cut into submerchantable lengths to remove and/or trees could not be accessed without major effort (e.g., a large tree build into a deck) or a high likelihood of property damage. 


\section{Data Analysis}

\section{Tree Wood Volume Estimation}

Stem measurements were used to estimate the total merchantable saw timber round wood volume $\left(\mathrm{m}^{3}\right)$ in each sample tree from $0.15 \mathrm{~cm}$ (0.06 in) stump height to an approximate $20 \mathrm{~cm}$ (8 in) top DOB with Smalian's formula (Avery and Burkhart 1994). An individual taper model for each tree derived from its top diameter and dbh was used to account for stem taper during volume calculations (change in stem diameter over log length was extrapolated to predict stump diameter outside bark for each tree). A species-level constant bark factor model, predicting wood volume inside bark from wood volume outside bark, was used to estimate solid wood and bark volumes from total volume (Smith 1985). Exotic tree species were assigned a bark factor of a species in the same genera with an equivalent bark type. Recovered sawn lumber volume in standing trees was computed using the tree's taper model and the International $1 / 4$ in Board-foot rule for variable length logs (Freese 1973) so that recovered saw lumber could be compared with cubic round wood volume estimates (i.e., accounting for losses attributable to sawing). Crown wood board-foot volume was estimated using a model relating the basal area $\left(\mathrm{BA}_{\mathrm{i}}, \mathrm{ft}^{2}\right)$ and the number of merchantable $8 \mathrm{ft}$ $(26.4 \mathrm{~m})$ saw $\operatorname{logs}\left(\mathrm{L}_{\mathrm{i}}\right)$ in the crown of a tree to its International $1 / 4$ in Board-foot rule volume $\left(\mathrm{V}_{\mathrm{Si}}\right): \mathrm{V}_{\mathrm{Si}}=19.30\left(\mathrm{BA}_{\mathrm{i}}\right.$ $\left.\mathrm{L}_{\mathrm{i}}\right)^{0.74}$ derived from felled and dissected trees on Michigan timberlands (MacFarlane, unpublished).

\section{Scaling Up Individual Tree Estimates to the 13-County Region}

Average saw timber volume per hectare $\left(\mathrm{m}^{3}\right.$ and bd $\left.\mathrm{ft}\right)$ was estimated from the number of sample trees $20 \mathrm{~cm}$ ( $8 \mathrm{in}) \mathrm{dbh}$ or greater on a sample plot with an area $a_{\mathrm{i}}$. The contribution of each sample tree to per hectare estimates was weighted according to its selection probability, which was proportional to the size of the variable area plot on which it occurred (Shiver and Borders 1996); the variance of sample means was also weighted in the same way. Estimates from each of the LULC classes were then combined to estimate the overall urban condition for the 13-county region using typical procedures for combining stratum in stratified sampling (Shiver and Borders 1996) with contributions of plots from each LULC weighted by the fraction of urban area they comprised (Table 1).

\section{RESULTS}

Overall, 76 urban QQSs were surveyed and 1887 stems and stumps $20 \mathrm{~cm}$ (8 in) or greater were measured translating into a mean density of $12.8[ \pm 2.1$ (standard error of mean) stems and stumps ha ${ }^{-1}\left(5.8[ \pm 0.8] \mathrm{ac}^{-1}\right)$ across the 13-county urban area; $89.7 \%$ were healthy, live trees, $6.3 \%$ were classed as dying, $3.7 \%$ were stumps, and $0.3 \%$ were dead, standing trees. Estimated density values for LULCs were $9.5[ \pm 3.1]$, $13.7[ \pm 3.5], 18.8[ \pm 4.2]$, and $20.3[ \pm 3.7]$ stems and stumps $\mathrm{ha}^{-1}$ for high-intensity urban, low-intensity urban, parks and golf courses, and roads and paved areas, respectively. At least 68 species (with $20 \mathrm{~cm}$ [8 in] or greater) representing 36 genera were found (some trees were only identified to their generic scientific name and species could not be identified for all stumps); each was assigned to a species-product class (see Appendix) based on U.S.D.A. Forest Inventory and Analysis groupings (Miles et al. 2001).

\section{Urban Wood Volume Grade and Species-Products}

The mean urban (round) wood volume across the 13-county area in tree stem sections $20 \mathrm{~cm}$ (8 in) or greater dbh was estimated to be $7.9[ \pm 1.3] \mathrm{m}^{3} / \mathrm{ha}^{-1}\left(117.2 \pm 19.9 \mathrm{ft}^{3} / \mathrm{ac}^{-1}\right)$, $\approx 31 \%$ of which was graded as having no saw timber value (grade 0; Table 2) as a result of major rot, defects, and other problems (see Rast et al. 1973). Approximately 56\% of all graded (not including crown wood) softwood volume per acre was deemed as having no saw timber value, whereas only $35 \%$ of potentially commercial hardwood stems were graded as unfit for saw timber products (Table 2). Approximately $73 \%$ of all stems of "noncommercial" species (Table 1) were rated as unsuited for saw timber. Less than $5 \%$ of red oak (shingle oak, Quercus imbricaria; pin oak, Q. palustris; northern red oak, $Q$. rubra; black oak, $Q$. velutina), white oak (white oak, $Q$. alba; swamp white oak, $Q$. bicolor; bur oak, $Q$. macrocarpa; English oak, Q. robur), and black walnut ( $\mathrm{Ju}$ glans nigra) wood was rated as having no value, whereas a large proportion of hard maple (58\%) (hedge maple, Acer campestre; black maple, A. nigrum; sugar maple, A. saccharum) and soft maple (42\%) (boxelder, A. negundo; Norway maple, A. platanoides; red maple, A. rubrum; silver maple, $A$. saccharinum) wood was graded as having no saw timber value.

Approximately $60 \%$ of mean urban wood volume was saw timber grade (grades 1 through 5; Table 2) amounting to 4.7 $\mathrm{m}^{3} / \mathrm{ha}^{-1}[ \pm 0.9]\left(67.7[ \pm 13.3] \mathrm{ft}^{3} / \mathrm{ac}^{-1}\right)$. Mean saw timber (round) wood volume translated into $1364 \mathrm{bd} \mathrm{ft}$ per urban hectare $\left(552 \mathrm{bd} \mathrm{ft} / \mathrm{ac}^{-1}\right)$ of sawn lumber using the International $1 / 4$ in rule (a conversion ratio of $290 \mathrm{bd} \mathrm{ft}$ per cubic meter of wood [8.2 bd ft/ft $\left.{ }^{3}\right]$ ). Most (93\%) of urban softwood saw timber volume assigned to the lowest class (grade 3 ). This likely was the result of the greatly increased size and density of branch knots in open-grown coniferous trees, which are reflected in softwood grading rules (DeBell et al. 1994; Uusitalo and Isotalo 2005). In general, a smaller proportion of urban hardwood saw timber volume was in higher grade classes than in lower grade classes (11\% grade 1, 13\% grade 2, 24\% grade 3, and 48\% grade 5) except for grade 4, construction grade, which comprised only $4 \%$. The latter reflects reservations by field technicians regarding the potential 
Table 2. Mean volume $\left(\mathrm{m}^{3} / \mathrm{ha}^{-1}\right)$ of tree stem and branch sections $20 \mathrm{~cm}(8 \mathrm{in})$ or greater in diameter in urban areas of SE lower Michigan by species-product class and wood products grade. ${ }^{2}$

\begin{tabular}{|c|c|c|c|c|c|c|c|c|c|c|}
\hline \multirow[b]{2}{*}{ Spp-product class } & \multicolumn{6}{|c|}{ Main stem grade } & \multirow[b]{2}{*}{ Crown } & \multirow{2}{*}{$\begin{array}{l}\text { Total } \\
\text { volume }\end{array}$} & \multirow{2}{*}{$\begin{array}{l}\text { Total grade } \\
(1-5)\end{array}$} & \multirow{2}{*}{$\begin{array}{l}\% \text { Crown } \\
\text { wood }\end{array}$} \\
\hline & 0 & 1 & 2 & 3 & 4 & 5 & & & & \\
\hline \multicolumn{11}{|l|}{ Softwoods } \\
\hline Spruce-fir & 0.3177 & - & 0.0021 & 0.2831 & - & - & - & 0.6029 & 0.2852 & $0.00 \%$ \\
\hline White-red pine & 0.1619 & - & 0.0035 & 0.1128 & - & - & 0.0032 & 0.2812 & 0.1162 & $1.13 \%$ \\
\hline Other pine & 0.1218 & 0.0079 & 0.0193 & 0.0173 & - & - & 0.0012 & 0.1675 & 0.0445 & $0.74 \%$ \\
\hline Other softwoods & 0.0046 & - & - & 0.0389 & - & - & 0.0002 & 0.0437 & 0.0389 & $0.44 \%$ \\
\hline Douglas-fir & 0.0025 & - & - & 0.0040 & - & - & - & 0.0065 & 0.0040 & $0.00 \%$ \\
\hline All softwoods & 0.6084 & 0.0079 & 0.0249 & 0.4560 & - & - & 0.0046 & 1.1018 & 0.4887 & $0.42 \%$ \\
\hline \multicolumn{11}{|l|}{ Hardwoods } \\
\hline Soft maple & 1.0385 & 0.0032 & 0.0737 & 0.0918 & 0.0069 & 0.8172 & 0.4131 & 2.4444 & 0.9928 & $16.90 \%$ \\
\hline Poplar & 0.0951 & 0.2366 & 0.1398 & 0.2550 & 0.0034 & 0.0390 & 0.0586 & 0.8275 & 0.6738 & $7.08 \%$ \\
\hline Red oak & 0.0070 & 0.0309 & 0.1040 & 0.2458 & 0.0210 & 0.2405 & - & 0.6494 & 0.6423 & $0.00 \%$ \\
\hline Ash & 0.0718 & 0.0924 & 0.0853 & 0.0203 & 0.0164 & 0.2527 & 0.0162 & 0.5550 & 0.4670 & $2.92 \%$ \\
\hline Other soft hardwoods & 0.1844 & 0.0179 & - & 0.1010 & 0.0229 & 0.2421 & 0.0505 & 0.6188 & 0.3839 & $8.16 \%$ \\
\hline White oak & 0.0130 & 0.0181 & 0.0130 & 0.1157 & 0.0352 & 0.1037 & 0.0596 & 0.3583 & 0.2856 & $16.65 \%$ \\
\hline Hickory & 0.0555 & - & 0.0017 & 0.0956 & 0.0371 & 0.0308 & 0.0152 & 0.2359 & 0.1652 & $6.44 \%$ \\
\hline Walnut & 0.0016 & 0.0248 & 0.0747 & 0.0254 & - & 0.0329 & 0.0037 & 0.1632 & 0.1578 & $2.26 \%$ \\
\hline Other hard hardwoods & 0.0810 & 0.0050 & 0.0088 & 0.0333 & 0.0101 & 0.0928 & 0.0424 & 0.2735 & 0.1501 & $15.52 \%$ \\
\hline Hard maple & 0.2082 & 0.0013 & 0.0175 & 0.0376 & 0.0184 & 0.0622 & 0.0142 & 0.3594 & 0.1370 & $3.96 \%$ \\
\hline Basswood & 0.0399 & 0.0142 & 0.0197 & 0.0019 & - & 0.0657 & 0.0209 & 0.1624 & 0.1016 & $12.88 \%$ \\
\hline Birch & 0.0064 & - & - & - & - & 0.0622 & 0.0024 & 0.0710 & 0.0622 & $3.34 \%$ \\
\hline Yellow poplar & - & - & - & 0.0001 & - & - & - & 0.0001 & 0.0001 & $0.00 \%$ \\
\hline All hardwoods & 1.8025 & 0.4444 & 0.5383 & 1.0235 & 0.1715 & 2.0418 & 0.6969 & 6.7189 & 4.2195 & $10.37 \%$ \\
\hline Noncommercial & 0.0633 & - & 0.0089 & 0.0056 & - & 0.0094 & 0.0116 & 0.0989 & 0.0239 & $11.75 \%$ \\
\hline All spp-product classes & 2.4742 & 0.4523 & 0.5721 & 1.4851 & 0.1715 & 2.0512 & 0.7131 & 7.9196 & 4.7322 & $9.00 \%$ \\
\hline
\end{tabular}

${ }^{\mathrm{z}}$ Crown logs were not graded.

Dashes indicate no trees of this type were found during sampling.

strength and durability of urban-grown saw timber trees (i.e., these were conservatively placed in grade 5).

Approximately $89 \%$ of all urban saw timber volume $(4.2$ $\mathrm{m}^{3} / \mathrm{ha}^{-1}$ ) was comprised of wood from commercially recognized hardwood species, $10 \%$ from commercial softwood species $\left(0.5 \mathrm{~m}^{3} / \mathrm{ha}^{-1}\right)$, and the remaining $1 \%$ from noncommercial species (Table 2). Approximately one-fourth of all commercial hardwood saw timber was comprised of soft maple alone, and nearly two-thirds was comprised of soft maple, poplar (bigtooth aspen, Populus grandidentata; quaking aspen, $P$. tremuloides; cottonwood, $P$. deltoides), ash (white ash, Fraxinus americana; European ash, F. excelsior; green ash, $F$. pennsylvanica), and red oak (Table 2). Black walnut, red oak, and poplar trees had more than double the average proportion of high-grade wood (grades 1 through 3 ) in them, whereas the majority of saw timber from soft maples and other hard and other soft hardwood species (mostly honeylocust [Gleditsia triacanthos] and elm [Ulmus americana, $U$. pumila], respectively) was rated in the lowest lumber grade classes (4 and 5; Table 2). More than three-fourths of all softwood saw timber was comprised of low-grade sprucefir (Colorado blue spruce, Picea pungens; Norway spruce,
P. abies; white spruce, P. glauca; white fir, Abies concolor $)$ and white (Pinus strobus) and red pines (P. resinosa).

Across all species product-classes, $\approx 9 \%$ of mean urban wood volume (Table 2) was composed of crown logs of variable (unknown) quality amounting to $0.7[ \pm 0.2] \mathrm{m}^{3} / \mathrm{ha}^{-1}$ $\left(10.2[ \pm 2.4] \mathrm{ft}^{3} / \mathrm{ac}^{-1}\right]$ of saw timber volume. The $0.7 \mathrm{~m}^{3} / \mathrm{ha}^{-1}$ of crown wood translated into $176 \mathrm{bd} \mathrm{ft} / \mathrm{ha}^{-1}\left(72 \mathrm{bd} \mathrm{ft} / \mathrm{ac}^{-1}\right)$ of ungraded urban saw timber. Over half of this $\left(0.4 \mathrm{~m}^{3} / \mathrm{ha}^{-1}\right)$ was found in the crowns of soft (mostly silver) maple trees. Honeylocust, cottonwood, elm, and white oak trees also had significant amounts of saw-grade branch wood. Noncommercial species (mostly willow [Salix spp.] and ornamental apple [Malus spp.] and cherry [Prunus spp.] trees) had a significant proportion of their potential sawn timber in their crowns, but the absolute amounts were trivial. Urban softwoods also had insignificant amounts of saw-grade branch wood (Table 2), which was not surprising given their naturally excurrent growth form.

\section{Regional Urban Saw Timber Abundance}

The overall weighted mean urban saw timber volume for stem and crown wood in the 13-county area was estimated to 
be $5.4[ \pm 1.7] \mathrm{m}^{3} / \mathrm{ha}^{-1}$, or $1540[ \pm 485] \mathrm{bd} \mathrm{ft} / \mathrm{ha}^{-1}$ accounting for conversion of round wood to dimensional lumber. There was considerable variation in saw timber volume both between and within different urban LULCs. Mean graded saw timber volume was $3.0[ \pm 1.2], 5.3[ \pm 1.6], 7.8[ \pm 2.1]$, and 7.4 $[ \pm 1.7] \mathrm{m}^{3} / \mathrm{ha}^{-1}$, respectively, for high-intensity urban, lowintensity urban, parks and golf courses, and roads and paved areas. Estimated crown wood saw timber volume for highintensity urban, low-intensity urban, parks and golf courses, and roads and paved areas was $0.4[ \pm 0.2], 0.7[ \pm 0.3], 1.0$ $[ \pm 0.3]$, and $2.1[ \pm 0.6] \mathrm{m}^{3} / \mathrm{ha}^{-1}$, respectively. Scaled up to the 13 -county region, this amounts to a total standing volume of 1.15 million $\mathrm{m}^{3}$ of urban saw timber $(\approx 327$ million bd $\mathrm{ft}$ of dimensional lumber) (Table 3).

\section{Accessibility}

To successfully recover saw timber from a tree, the tree must be accessible, i.e., able to be felled, cut in sections of merchantable length, and delivered to a sawmill (in urban areas, portable sawmills can ease the latter burden). Accessibility was not equal across all urban land types (Obviously, it should be much easier to harvest wood from street and parkland trees than from around homes and offices.). Approximately $93.5 \%$ of all saw timber on parks and golf courses was considered easily accessible and less than $1 \%$ difficult to access. Almost $90 \%$ of saw timber along roads and paved areas was rated as easily accessible, although street trees were approximately four times $(2.1 \%$ versus $0.5 \%)$ more likely to be rated as difficult to access than trees on parks and golf courses with the main complication being extracting wood from occasional large trees whose crowns are closely intertwined with utility wires. High-intensity urban areas posed a greater challenge for extracting saw timber from trees, although less than $4 \%$ of this saw timber was considered difficult to access. By sharp contrast, approxi- mately half of all saw timber in low-intensity urban areas was rated as difficult to access. This reflects the close proximity of many large trees to hazards (sense Matheny and Clark 1994) such as homes or fences, in low-intensity urban areas, that would necessitate extraordinary measures to harvest trees in standard log lengths. Based on the weighted contribution of each of the four urban LULCs to total urban area (Table 1), it was estimated that $\approx 56 \%$ of all urban saw timber in the 13 -county area was easily accessible, another $16 \%$ would require some additional measures to extract that would add additional costs (moderately accessible), and the remaining $28 \%$ difficult (for most intents and purposes considered inaccessible). Thus, of the total standing urban saw timber, $\approx 72 \%$ was considered accessible for extraction, amounting to $825,000 \mathrm{~m}^{3}$ of urban saw timber $(\approx 235$ million bd $\mathrm{ft}$ of dimensional lumber) (Table 3).

\section{Annual Yield}

The $825,000 \mathrm{~m}^{3}$ of urban saw timber that is accessible in the 13-county areas includes all standing trees, virtually all of which would not be harvested until the trees that contain them were dead, or at minimum dying. Thus, to calculate the availability of urban saw timber on an annual basis, it was necessary to estimate the rate at which trees would become available. However, mortality rates and removal rates could not be directly assessed from the data collected for this study (stumps, e.g., represent death events from different years and may be ground up and seeded over and thus might not be tallied at all). Instead, recent estimates by Nowak et al. (2004) describing general trends and specific tree removal and mortality rates were combined with the data presented here and used to make reasonable estimates of urban saw timber availability on an annual basis.

Nowak et al. (2004) suggested that standing trees in apparently good condition die at a rate of $\approx 1.4 \%$ per year. The

Table 3. Saw timber volume estimates $\left(\mathrm{m}^{3}\right)$ for urban portions of 13 counties in southeastern lower Michigan.

\begin{tabular}{lccr}
\hline County & Total standing & Accessible & Annual yield \\
\hline Genesee & $109,358(34,428)$ & $78,738(24,788)$ & $1575(496)$ \\
Ingham & $57,5(18,124)$ & $41,450(13,049)$ & $829(261)$ \\
Jackson & $41,013(12,912)$ & $29,529(9296)$ & $591(186)$ \\
Lapeer & $15,426(4856)$ & $11,107(3497)$ & $222(70)$ \\
Lenawee & $22,094(6956)$ & $15,908(5008)$ & $318(100)$ \\
Livingston & $38,813(12,219)$ & $27,945(8798)$ & $559(176)$ \\
Macomb & $157,526(49,591)$ & $113,419(35,706)$ & $2,268(714)$ \\
Monroe & $34,835(10,967)$ & $25,081(7896)$ & $502(158)$ \\
Oakland & $226,736(71,380)$ & $163,250(51,394)$ & $3,265(1028)$ \\
Shiawassee & $18,971(5972)$ & $13,659(4300)$ & $273(86)$ \\
St. Clair & $36,594(11,520)$ & $26,348(8295)$ & $527(166)$ \\
Washtenaw & $60,017(18,894)$ & $43,212(13,604)$ & $864(272)$ \\
Wayne & $327,415(103,075)$ & $235,739(74,214)$ & \\
13-county area & $1,146,368(360,894)$ & $825,385(259,844)$ & \\
\hline
\end{tabular}

Standard errors in parentheses. 
latter rate was used to describe mortality in the "live" category in this study, $1.4 \%$ of the $89.7 \%$ of urban stems per acre or $1.3 \%$. Trees with crown deterioration, equating roughly to "dying" trees in this study, had a mortality rate of $\approx 6.4 \%$ (Nowak et al. 2004), which equates to $0.4 \%$ more of the trees in this study. Ignoring the stumps, another $0.3 \%$ can be tallied from dead standing trees that have not yet been removed. All totaled, it can be expected that $\approx 2 \%$ of the accessible volume would come available annually, which translates into $\approx 16,500 \mathrm{~m}^{3}$ (or $\approx 4.7$ million bd $\mathrm{ft}$ ) of urban saw timber per year available in the 13-county study area (Table 3).

\section{DISCUSSION}

The methods presented here allowed for a regional estimate of urban saw timber to be developed and extrapolated through urban land area estimates derived from satellite photography. Data describing urban land cover are generally widely available (e.g., the entire United States; Nowak et al. 2006); thus, these methods could be replicated almost anywhere. To the extent that average per hectare estimates derived from urban areas in southeastern lower Michigan are representative of broader regional species composition and urban tree demographic structure, these specific estimates could be further extrapolated outside of this specific region. However, the overall weighted estimates are also sensitive to the relative makeup of urban areas (e.g., a different ratio of high- versus low-intensity urban areas) such that per hectare estimates for urban LULCs would need to be reweighted accordingly.

Over $16,000 \mathrm{~m}^{3}$ of urban saw timber is estimated to come available each year in the 13-county study area. To put this number in perspective, small modern sawmills process $\approx 3000$ to $10,000 \mathrm{~m}^{3}$ of wood per year annually (Pascal Kamdem, Michigan State University, pers. com.). Assuming a minimum of $3000 \mathrm{~m}^{3}$ to remain viable, all of the potentially available wood in the 13 counties that comprise southeastern lower Michigan could support the minimum annual needs of five of these mills. The 4.7 million bd ft of lumber annually available in urban trees in this region is equivalent to the amount of wood used to build 362 average-sized homes (Falk 2002).

The quality of wood in urban softwoods was generally low based on the grading standards applied, which was not surprising given the importance of maintaining small branch knots along the main stem of (coniferous) trees to softwood quality; a condition most likely to be met when trees are forest grown (DeBell et al. 1994; Uusitalo and Isotalo 2005). However, most urban saw timber $(\approx 90 \%)$ inventoried came from commercially viable hardwood timber species, $60 \%$ of which was considered saw-grade quality. Whereas noncommercial species comprise a trivial proportion of large trees, wood from exotic species did comprise a substantial proportion of urban wood (e.g., Siberian elm, Norway maple, and horsechestnut), raising potential concerns regarding their utilization (e.g., commercial kiln-drying procedures have not been developed for them). However, wood from many of these species are already commercially viable (Norway maple is considered a valuable hardwood in Germany; Jurek and Wihs 1998), and some North American vendors have been able sell wood from exotic tree species at a premium (www. urbantreesalvage.com).

One aspect of urban wood quality not addressed by this study is that of the mechanical properties of urban wood. Mackes et al. (2005) found that the modulus of rupture and modulus of elasticity were both lower in open-grown trees, primarily attributable to a greater quantity of juvenile wood, which suggests a potentially lower strength for "urban" wood. Further research would have to be done to specifically measure wood properties of urban versus forest-grown trees.

The estimates of urban saw timber presented here are likely conservative based on the definitions of "urban" area used in this study. The use of remotely sensed land use/land cover imagery to define urban areas likely underestimates the number of trees in urban areas relative to definitions based on political boundaries such as city limits or census districts (e.g., Nowak et al. 2006), which, if used, would have included wood from trees growing in forested areas within urban zones. It also likely underestimates the total amount of urban area. In a recent study, Fang et al. (2006) demonstrated that land use maps were more likely to misclassify urban areas (in Chicago) as forested than the reverse, because of the fact that many houses were beneath a canopy of trees.

Estimates of urban saw timber availability were also likely conservative based on definitions of what portion of urban wood qualified as extractable sawn wood products. Lowintensity urban areas comprised almost half of all urban area in the 13-county region (Table 1) and almost 50\% of the wood in these areas was rated as difficult to access attributable to a frequent close proximity of large trees to potential hazards (e.g., homes). Sherrill (2003) proposed reasonable guidelines for safely extracting urban wood and commercial arborists to safely remove such trees all the time; thus, a larger proportion of wood from these trees may actually be accessible. Advances in sawing technology might also allow portions of some of the wood rated as grade 0 to be used for saw timber. Typical modern sawmills often dissect logs into a variety of component parts of different grades such that the visually based whole log or tree stem grading rules used here (e.g., Rast et al. 1973) may be overly conservative.

Estimates also did not include the solid wood products potential of trees smaller than $20 \mathrm{~cm}$ (8 in) diameter. Advances in wood technology have greatly expanded the potential for smaller trees (LeVan-Green and Livingston 2001). However, by extrapolating volume estimates for trees of different sizes measured in this study, it was estimated that trees less than $20 \mathrm{~cm}$ ( 8 in) contribute only $\approx 3 \%$ to the total un- 
processed volume, thus smaller diameter urban trees would likely contribute very little additional lumber.

Because most saw timber is harvested from forest-grown trees, it may be useful to compare the quality and availability of urban saw timber with that available from forests. Based on data from the U.S.D.A. Forest Inventory and Analysis program (Unit 4, Michigan, cycle 6, 2004), $5055 \mathrm{bd} \mathrm{ft} / \mathrm{ac}^{-1}$ $\left(12,486 \mathrm{bd} \mathrm{ft} / \mathrm{ha}^{-1}\right)$ of graded saw timber is available on an average forested acre in southern lower Michigan, which is approximately nine times what was estimated for an average urban acre (552 bd ft/ac $\mathrm{ac}^{-1}$ ). Ignoring softwoods in our study, which were not graded into all five U.S.D.A. Forest Services tree grades (see "Methods"), $\approx 59 \%$ of all forest-grown bd.ft. were in factory-grade classes $(1,2$, and 3$)$ and $41 \%$ in the construction and local use classes (grades 4 and 5), compared with $54 \%$ and $46 \%$, respectively, for urban hardwood saw timber volume (Figure 1). Within the upper saw grades, forest- versus urban-grown hardwood saw timber volume was $14 \%$ versus $10 \%$ in grade class $1,19 \%$ versus $12 \%$ in grade class 2 , and $27.0 \%$ versus $32 \%$ for grade class 3 , respectively. Thus, in an absolute sense, there are clearly many more saw timber quality trees in forested versus urban areas, but these results suggest only a small difference in wood quality relative to the large $(900 \%)$ decrease in wood quantity when one harvests hardwood trees in urban versus forested areas.

Despite the potential availability of urban saw timber demonstrated here, there are still outstanding logistical problems regarding successful capitalization of it, including costs of extraction, handling, and variation in supply. One fact regarding urban trees, however, is the inevitability of their removal once they become dead or diseased, because they represent a liability (a hazard, sense Matheny and Clark 1994) and diminish aesthetic value (Scott and Betters 2000). Nowak et al. (2004) estimated that $17 \%$ of all dead standing trees in Baltimore, Maryland, were removed over a 2-year period, or $\approx 8.5 \%$ per year. This suggests some consistent level of urban wood will be available for harvest over time.

One caveat regarding capitalizing on urban wood made available through tree sickness and mortality is the need to properly sanitize diseased or infested trees to prevent further dissemination of the pests and pathogens that injured or killed them. A primary vector for spread of emerald ash borer, e.g., is through transportation of infested firewood to new areas (Poland and McCullough 2006). Because emerald ash borer, and most other pests and pathogens of tree stems, live and feed in the phloem, debarking trees and stripping off a small bit of the outermost wood can be a simple and highly effective treatment so long as these residual materials are properly disposed of (this has been examined for sanitizing emerald ash borer-infested ash logs in Michigan). Other methods suggested include treating infested logs with pesticides (Nzokou et al. 2006a) or preservatives (Nzokou et al. 2006b), but there

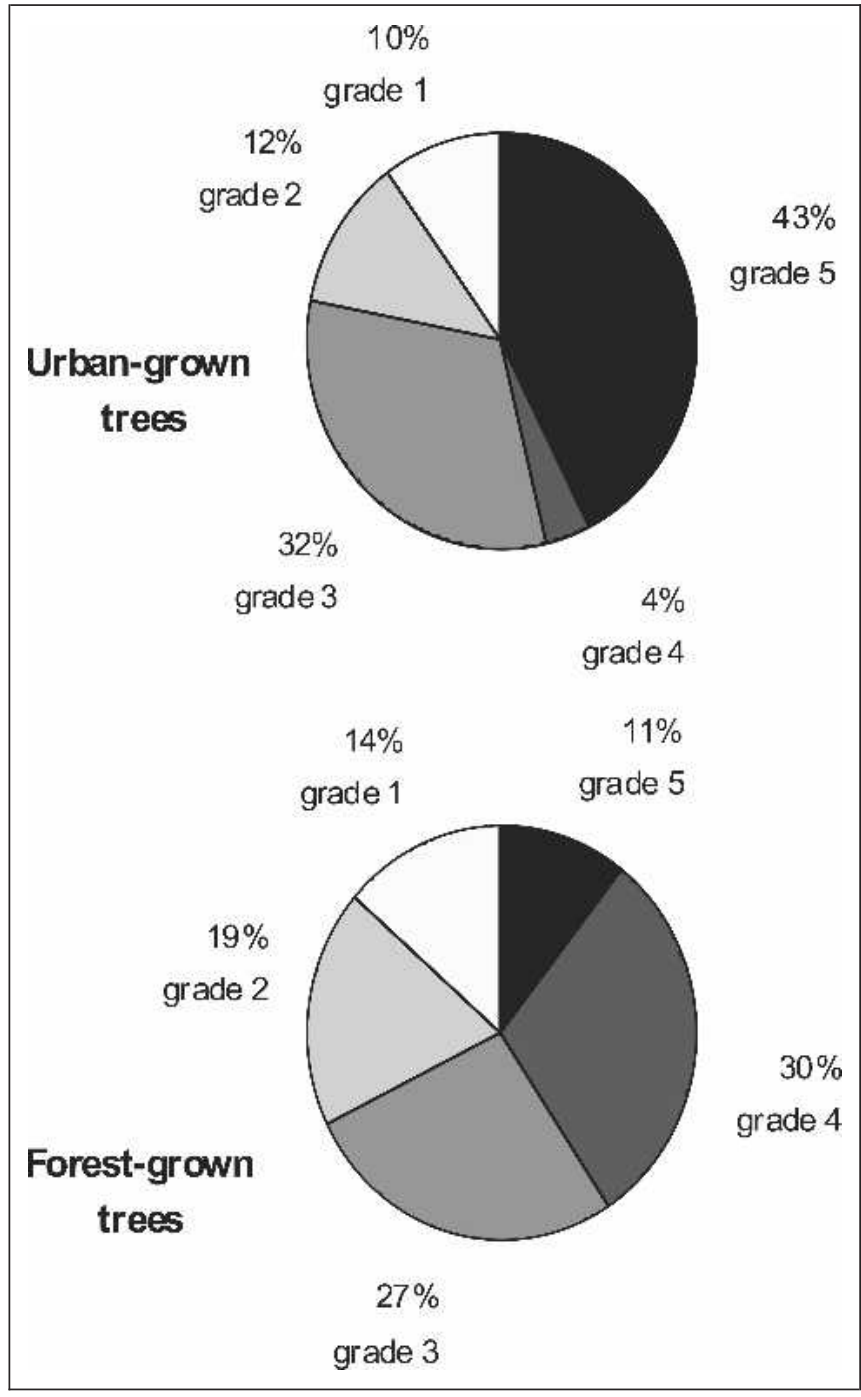

Figure 1. Comparison of saw timber quality grades (grade 1 is the highest grade) between urban- and forest-grown trees in southern lower Michigan.

are challenges to implementing such treatments at large scales.

Although it may not be realistic to expect arborists and small, private landowners to bear the logistical or financial burden of harvesting urban saw timber, clearly public entities could expand the current level of efforts. For example, the Community and Urban Forest Inventory and Management (computer) Program was recently created to help communities in California to inventory tree volume and calculate value for their urban forests (Pillsbury and Gill 2003). It has already been demonstrated on smaller scales that internal utilization of dead and dying municipal trees can offset the costs of tree removal and allow reduced infrastructural costs such as the purchase of wood for park benches and picnic pavilions (Bratkovich 2001). Training municipal foresters to grade 
trees would be an important first step toward differentiating the value of dead and dying trees. The alternative is to continue to put valuable wood products contained in urban trees to some lesser use (e.g., firewood) or, as a worst case, into a landfill (urban wood waste comprises $\approx 17 \%$ of all waste received at U.S. landfills; Solid Waste Association of North America 2002).

\section{CONCLUSION}

Recent economic losses associated with the destruction of urban trees by wood-boring forest pests such as the emerald ash borer highlights the well-known value associated with urban forests, not the least of which may be the valuable wood in the trees. Although there are potential concerns with harvesting urban trees for saw timber such as low availability and poor wood quality, the results of this study suggest that many of them may be unfounded. Harvesting urban wood is certainly less efficient relative to commercial logging in forests because, even if abundant, urban wood may be scattered around a large metropolitan area in smaller saleable units, greatly increasing the cost of consolidating and transporting it. However, it may not be prudent to view urban wood as an alternative to wood derived from forests. Rather, it might best be viewed as a supplementary source of wood that may help to offset the social and economic costs of urban tree removal and urban wood waste disposal to private landowners and government entities. Clearly, if southeastern lower Michigan is similar to other regions nationwide, a substantial amount of wood products volume is available from trees in urban areas.

Acknowledgments. I thank the Southeast Michigan Resource Conservation and Development Council and the Michigan Agricultural Experiment Station for providing funding and resources for this research. I also thank Sam Sherrill and Pascal Kamdem for thoughtful comments regarding this research. I thank John Kemppainen, Sean Flinn, and Hong Su An for spending many hours knocking on doors and measuring urban trees.

\section{LITERATURE CITED}

Avery, T.E., and H.E. Burkhart. 1994. Forest Measurements. 4th edition. McGraw-Hill, Inc., New York.

Bratkovich, S.M. 2001. Utilizing Municipal Trees: Ideas from Across the Country. NA-TP-06-01, St. Paul, MN: USDA, Forest Service, Northeastern Area, State and Private Forestry.

DeBell, J.D., J.C. Tappenier, and R.L. Kramer. 1994. Brach diameter of western hemlock: Effects of precommercial thinning and implications for log grades. Western Journal of Applied Forestry 9:88-90.

Falk, B. 2002. Wood-framed building deconstruction: A source of lumber for construction? Forest Products Journal 52:8-15.

Fang, S., G. Gertner, G. Wang, and A. Anderson. 2006. The impact of misclassification in land use maps in the pre- diction of landscape dynamics. Landscape Ecology 21: 233-242.

Freese, F. 1973. A Collection of Log Rules. Gen. Tech. Rep. FPL-01. Madison, WI: U.S. Department of Agriculture, Forest Service, Forest Products Laboratory. U.S. Government Printing Office, 754-546/28.

Johnson, A.D., and H.D. Gerhold. 2001. Carbon storage by utility-compatible trees. Journal of Arboriculture 27: 57-68.

Jurek, J., and U. Wihs. 1998. Norway maple in the city forest of Northeim. Site requirements and growth. Forst-undHolz 53:15-18.

LeVan-Green, S.L., and J. Livingston. 2001. Exploring the use for small-diameter trees. Forest Products Journal 51: $10-21$.

Mackes, K., W. Sheppard, and C. Jennings. 2005. Evaluating the bending properties of clear wood specimens produced from small-diameter ponderosa pine trees. Forest Products Journal 55:72-80.

Matheny, N.P., and J.R. Clark. 1994. A Photographic Guide to the Evaluation of Hazard Trees in Urban Areas. 2nd edition. International Society of Arboriculture, Urbana, IL.

McPherson, E.G., J.R. Simpson, P.J. Peper, and Q. Xiao. 1999. Benefit-cost analysis of Modesto's municipal urban forest. Journal of Arboriculture 25:235-248.

Michigan Department of Natural Resources (MDNR). Forest Mineral and Fire Management Division. 2003. IFMAP/ GAP Lower Peninsula Land Cover. Michigan Department of Natural Resources, Ann Arbor, MI. www.dnr.dtate.mi. us/spatialdatalibrary/sdl2/land_use_cover/2001/IFMAP_ lp_landcover.htm (accessed 9/20/04).

Miles, P.D., G.J. Brand, C.L. Alerich, L.F. Bednar, S.W Woudenberg, J.F. Glover, and E.N. Ezzell. 2001. The Forest Inventory and Analysis Database: Database Description and Users Manual, Version 1. GTR NC-218, U.S.D.A. Forest Service, North Central Forest Experiment Station.

NOAA CSCC-CAP. 2003. Late-date Classification of the Lower Peninsula of Michigan. National Oceanic and Atmospheric Administration (NOAA) Coastal Services Center (CSC)/Coastal Change Analysis Products(CCAP), Charleston, SC.

Nowak, D.J., and D.E. Crane. 2002. Carbon storage and sequestration by urban trees in the USA. Environmental Pollution 166:381-389.

Nowak, D.J., M. Kuroda, and D.E. Crane. 2004. Tree mortality rates and tree population projections in Baltimore, Maryland, USA. Urban Forestry and Urban Greening 2: 139-147.

Nowak, D.J., J.E. Pasek, R.A. Sequeira, D.E. Crane, and V.C. Mastro. 2001. Potential Effect of Anoplophora glabripennis (Coleoptera: Cerambycidae) on urban trees in the United States. Journal of Economic Entomology 94: 116-122. 
Nowak, D.J., J.T. Walton, J.F. Dwyer, L.G. Kaya, and S. Meyong. 2006. The increasing influence of urban environments on U.S. forest management. Journal of Forestry 103:377-382.

Nzokou, P., S.M. Pankras, and D.P. Kamdem. 2006a. Preservative treatment of ash wood from emerald ash borer (Agrilus planipennis) infested trees. Forest Products Journal 56:69-72.

Nzokou, P., T.R. Petrice, R.A. Haack, and D.P. Kamdem. 2006b. Borate and imidacloprid treatment of ash logs infested with the emerald ash borer. Forest Products Journal $56: 78-81$.

Pillsbury, N.H., and S.J. Gill. 2003. A User Guide for CUFIM, the Community and Urban Forest Inventory and Management Program. Tech. Report No. 11, Urban Forest Ecosystems Institute, California Polytechnic State University, San Luis Obispo, CA.

Poland, T.M., and D.G. McCullough. 2006. Emerald ash borer: Invasion of the urban forest and the threat to North America's ash resource. Journal of Forestry 104:118-124.

Rast, E.D., D.L. Sonderman, and G.L. Gammon. 1973. A Guide to Hardwood Log Grading. GTR-NE-1, U.S.D.A. Forest Service, Northeastern Forest Experiment Station.

Scott, J.L., and D.R. Betters. 2000. Economic analysis of urban tree replacement decisions. Journal of Arboriculture 26:69-77.

Sherrill, S.B. 2003. Harvesting Urban Timber: A Guide to Making Better Use of Urban Trees. Linden Publishing Inc., Fresno, CA.

Shiver, B.D., and B.E. Borders. 1996. Sampling Techniques for Forest Resource Inventory. John Wiley and Sons, Inc., New York.

Smith, W.B. 1985. Factors and Equations to Estimate Forest Biomass in the North Central Region. U.S.D.A. Forest Service, North Central Forest Experiment Station, Research Paper NC-268.

Solid Waste Association of North America. 2002. Successful Approaches to Recycling Urban Wood Wastes. Gen. Tech. Rep. FPL-GTR-133. U.S.D.A., Forest Service, Forest Products Laboratory, Madison, WI.

Uusitalo, J., and J. Isotalo. 2005. Predicting knottiness of Pinus sylvestris for use in tree bucking procedures. Scandinavian Journal of Forest Research 20:521-533.

Zakrzewski, W.T., and D.W. MacFarlane. 2006. Regional stem profile model for cross-border comparisons of harvested red pine (Pinus resinosa Ait.) in Ontario and Michigan. Forest Science 52:468-475.

David W. MacFarlane

Department of Forestry Michigan State University

126 Natural Resource Building

East Lansing, MI 48824, U.S.

macfar24@msu.edu
Résumé. Il y a besoin croissant dans la société pour employer des ressources efficacement, et ce incluant l'utilisation des arbres morts ou mourants en milieux urbains. La récolte des billes de sciage à partir des arbres urbains constitue une utilisation ultime, mais la plupart du temps le bois se retrouve enfoui, déchiqueté en copeaux de bois ou encore est employé comme biomasse pour la production d'énergie. Pour évaluer la faisabilité générale de récolter le bois en milieu urbain, une estimation régionale de la quantité de bois de sciage, de sa qualité et de disponibilité a été faite auprès de 13 comtés dans le Sud-Est du Bas Michigan. De manière conservatrice, un volume de plus de $16000 \mathrm{~m}^{3}$ de bois de sciage a été estimé comme étant disponible annuellement à partir des arbres morts ou mourants au sein de cette étude, ce qui s'avérait suffisant pour assurer l'approvisionnement annuel minimum de cinq petites scieries. La qualité du bois mou en milieu urbain s'avérait plutôt faible, mais ce elle ne comptait que pour $10 \%$ du volume total récoltable en milieu urbain. La qualité des bois durs en milieu urbain s'avérait quant à elle comparable à celle retrouvée dans les forêts de la région, et ce même si les volumes absolus disponibles étaient de neuf fois inférieur. Même s'il existe des inquiétudes potentielles à propos de la récolte d'arbres en milieu urbain pour des fins de sciage, telles que la faible disponibilité et la faible qualité du bois, les résultats de cette étude suggèrent que plusieurs d'entre elles pourraient s'avérer infondées.

Zusammenfassung. Es gibt eine wachsende Nachfrage nach effektiver Resourcennutzung, inklusive einer effektiven Nutzung von toten und sterbenden Bäumen in urbanen Gebieten. Die Holzernte von Stadtbäumen ist eine hochwertige Nutzung, aber viel Holz aus urbanen Regionen endet in Landverfüllungen oder wird für Hackschnitzel oder Biotreibstoff verwendet. Um die generellen Möglichkeiten von der urbanen Holzernte zu bewerten, wurde für eine Gegend mit 13 Kommunen in Lower Michigan eine regionale Schätzung der urbanen Holzquantität, -qualität und Verfügbarkeit vorgenommen. Konservativ werden jährlich über 16 Tausend $\mathrm{m}^{3}$ in dieser Region an Totholz und absterbenden Bäumen geerntet, genug, um den jährlichen Minimalbedarf von 15 Sägemühlen zu decken. Die Holzqualität von urbanen Weichhölzern ist allgemein niedrig, aber ihr Anteil beträgt auch nur $10 \%$ an der Gesamternte. Die Holzqualität von urban geernteten Harthölzern ist vergleichbar mit den im Wald der Region geernteten Harthölzern, obwohl das absolute Volumen nur den neunten Teil betrug. Während es möglicherweise Bedenken zur urbanen Holzernte gibt, wie geringe Verfügbarkeit oder schlechte Qualität, zeigt doch diese Studie, dass viele Bedenken unbegründet sind.

Resumen. Existe una creciente necesidad social por utilizar eficientemente los recursos, incluyendo el uso efectivo de árboles muertos y moribundos en áreas urbanas. La cosecha de madera para aserrío de los árboles urbanos está en uso, pero actualmente mucha de ella termina en rellenos o es usada para astillas o biomasa combustible. Con el propósito de evaluar la factibilidad de cosechar madera para aserrío se desarrolló una estimación regional de la cantidad, calidad y disponibilidad de madera urbana para un área del condado en el sureste del Bajo Michigan. Conservadoramente, se estima que 16 mil $\mathrm{m}^{3}$ de madera están disponibles cada año en el área de estudio de árboles muertos y moribundos, suficiente para satisfacer las necesidades mínimas anuales de 5 aserraderos pequeños. La cantidad de madera en los bosques de madera blanda fue 
generalmente baja, pero comprendió solamente una pequeña porción $(10 \%)$ de la madera urbana. La calidad de la madera de los bosques de madera dura fue comparable a la que se encuentra en los bosques nativos en la región, a pesar de que el volumen absoluto fue nueve veces menor. Con todo y que hay preocupación sobre la cosecha de los árboles urbanos para madera aserrada, tales como baja disponibilidad y pobre calidad de la madera, los resultados de este estudio sugieren que mucho de este temor es infundado.

\section{Appendix. Study species and FIA species-product class assignments.}

\section{FIA}

species-product

\begin{tabular}{|c|c|c|}
\hline group & Common name & Latin name \\
\hline \multirow[t]{3}{*}{ Ash } & Ash, European & Fraxinus excelsior \\
\hline & Ash, green & Fraxinus pennsylvanica \\
\hline & Ash, white & Fraxinus Americana \\
\hline \multirow[t]{2}{*}{ Basswood } & Basswood, American & Tilia americana \\
\hline & Linden, littleleaf & Tilia cordata \\
\hline \multirow[t]{2}{*}{ Birch } & Birch, river & Betula nigra \\
\hline & Birch, paper & Betula papyrifera \\
\hline Douglas-fir & Douglas-fir & Pseudotsuga menziesii \\
\hline \multirow[t]{3}{*}{ Hard maple } & Maple, black & Acer nigrum \\
\hline & Maple, hedge & Acer campestre \\
\hline & Maple, sugar & Acer saccharum \\
\hline \multirow[t]{4}{*}{ Hickory } & Hickory, bitternut & Carya cordiformis \\
\hline & Hickory, pignut & Carya glabra \\
\hline & Hickory, shagbark & Carya ovata \\
\hline & Hickory, shellbark & Carya laciniosa \\
\hline \multirow[t]{10}{*}{ Noncommercial } & Apple & Malus spp. \\
\hline & Ornamental cherry/plum & Prunus spp. \\
\hline & Gingko & Ginkgo biloba \\
\hline & Hawthorn & Crataegus spp. \\
\hline & Mountainash, American & Sorbus americana \\
\hline & Pear, callery & Pyrus calleryana \\
\hline & Olive-tree, Russian & Elaeagnus angustifolia \\
\hline & Tree-of-heaven & Ailanthus altissima \\
\hline & Willow & Salix spp. \\
\hline & Willow, black & Salix nigra \\
\hline \multirow{4}{*}{$\begin{array}{l}\text { Other hard } \\
\text { hardwoods }\end{array}$} & & \\
\hline & Chestnut & Castanea spp. \\
\hline & Honeylocust & Gleditsia triacanthos \\
\hline & Locust, black & Robinia pseudoacacia \\
\hline
\end{tabular}

\section{Appendix. Study species and FIA species-product class assignments. (continued)}

FIA

species-product

group Common name Latin name

Other pine Pine, Austrian Pinus nigra

Pine, Scotch

Pinus sylvestris

Other softwoods Baldcypress

Taxodium distichum

Redcedar, eastern Juniperus virginiana

Other soft

hardwoods White-cedar, northern

Thuja occidentalis

Buckeye

Catalpa, northern

Cherry, black

Elm, American

Elm, Siberian

Hackberry

Horsechestnut

Planetree, London

Mulberry, red

Sassafras

Sweetgum

Sycamore

Poplar

Aspen, bigtooth

Aspen, quaking

Cottonwood, eastern

Red oak

Oak, black

Oak, northern red

Oak, pin

Oak, shingle

Soft maple

Boxelder

Maple, Norway

Maple, red

Maple, silver

Spruce-fir

Fir, white

Spruce, Colorado blue

Spruce, Norway

Spruce, white

Walnut

Walnut, black

White oak

Oak, bur

Oak, English

Oak, swamp white

Oak, white

White-red pine Pine, eastern white

Pine, red

Aesculus spp.

Catalapa speciosa

Prunus serotina

Ulmus americana

Ulmus pumila

Celtis occidentalis

Aesculus hippocastanum

Platanus acerifolia

Morus rubra

Sassafras albidum

Liquidambar styraciflua

Platanus occidentalis

Populus grandidentata

Populus tremuloides

Populus deltoides

Quercus velutina

Quercus rubra

Quercus palustris

Quercus imbricaria

Acer negundo

Acer platanoides

Acer rubrum

Acer saccharinum

Abies concolor

Picea pungens

Picea abies

Picea glauca

Juglans nigra

Quercus macrocarpa

Quercus robur

Quercus bicolor

Quercus alba

Pinus strobus

Pinus resinosa

Yellow poplar Yellow-poplar

Liriodendron tulipifera 